International Journal of Social Science And Human Research

ISSN(print): 2644-0679, ISSN(online): 2644-0695

Volume 05 Issue 01 January 2022

DOI: 10.47191/ijsshr/v5-i1-03, Impact factor-5.586

Page No: $15-19$

\title{
Rohingya to Myanmar Military Coup: International Efforts in Respond to Humanitarian Violations and Myanmar's Democracy Deprivation
}

\author{
Rohannisa Naja Rachma Savitri ${ }^{1}$, Rizerius Eko Hadisancoko ${ }^{2}$, Marsono $^{3}$ \\ ${ }^{1,2,3}$ Department of Defense Diplomacy, Indonesia Defense University
}

\begin{abstract}
Myanmar is currently faced with conflicts mainly considered as crimes against humanity that require resolution sooner or later. The conflict in Myanmar is closely linked to ethnicity, creating a cycle of violence that continues to escalate without any possibility of diminishing. The inability of the state to address ethnic minority grievances or provide adequate security to communities has created a literal arms race among minority groups. More action needs to be taken to finally resolve the situation and crisis unfolding in Myanmar, and that is where countries in Southeast Asia play a very important role for conflict resolution. This research was carried out using qualitative method with descriptive analysis regarding to the situation that occurred in Myanmar, especially regarding the Rohingya crisis and the Myanmar Military Coup which was the focus of the research. The escalation of the humanitarian conflict and the deprivation of democracy by the Myanmar people, requires joint handling in order to avoid further expansion of the conflict. In this case, neighboring countries such as Indonesia have an important role as a driver of mediation in regional forums to resolve conflicts in Myanmar. ASEAN, as a diplomatic platform in the Southeast Asian region, must be put forward and reach a consensus for finally intervening in the Myanmar conflict, which is taking more and more lives. The United Nations with the principle of responsibility to protect can also play a role in overcoming the conflict, considering that the conflict has resulted in crimes against humanity that cannot be tolerated.
\end{abstract}

KEYWORDS: Myanmar Military Coup, Rohingya, Humanitarian Violation, Cooperation

\section{INTRODUCTION}

Conflict is defined as disagreement, disharmony, open or prolonged dispute, or can be defined as disagreement or friction. Conflict can be considered as an expression of hostility, negative attitude, antagonism, aggression, competition, and misunderstanding. When we define conflict based on its epistemology, conflict comes from the word "confligere" which means hitting each other. Conflict can be determined by the number of actors or groups involved, for example intra and interpersonal, intra and between groups, as well as intra and between countries. The level of conflict can be classified into three parts, namely individual level conflict, group level conflict, and organizational conflict. There are five types of conflict that can be found, namely individual, community, community, national, and international conflicts.

Currently there are two conflicts that occur in Myanmar, one of which is the Rohingya conflict which is still an ongoing conflict, and the coup that is currently being carried out by the Myanmar military. Both conflicts are considered crimes against humanity that require resolution sooner or later. The conflict in Myanmar is closely linked to ethnicity, creating a cycle of violence that continues to escalate without any possibility of diminishing. The inability of the state to address ethnic minority grievances or provide adequate security to communities has created a literal arms race among minority groups. The Rohingya genocide is the result of the Myanmar military government's deliberate policies and unplanned consequences that have led to a higher level of conflict between groups in Myanmar. In addition to the ethnic cleansing that is taking place in Myanmar, the country is faced with another conflict over a coup by the Myanmar military to seize power by detaining several politicians, including civilian leader Aung San Suu Kyi, whose party won in November's general election.

During decades of independence, Myanmar has struggled with military rule, civil war, isolation from global affairs and widespread poverty. However, the Myanmar military, or what we know as the Tatmadaw, maintains its dominance in many aspects of internal affairs. Military and civilian leaders have faced international condemnation for ongoing human rights abuses and brutal violence against civilians including Rohingya Muslims as a reported attempt to carry out genocidal intent (Maizland, 2021). The international community, in this case, needs to work together to prevent a larger-scale conflict and as a resolution to resolve the Myanmar conflict. Several countries have taken actions in response to the conflict in Myanmar such as medical 


\section{Rohingya to Myanmar Military Coup: The Role of International Organizations in Humanitarian Violations and Myanmar's Democracy Deprivation}

supplies, even opening borders for Rohingya civilians to flee. But more action needs to be taken to finally resolve the situation and crisis unfolding in Myanmar, and that is where countries in Southeast Asia play a very important role for conflict resolution.

\section{RESEARCH METHOD}

This research was carried out using qualitative method with descriptive analysis regarding to the situation that occurred in Myanmar, especially regarding the Rohingya crisis and the Myanmar Military Coup which was the focus of the research. The descriptive research is executed through the process of finding a problem that can be used as an object of this research through various social issues and phenomenon; and mapping of previous research and theories that can be used to analyze the object of this research (White \& Sabarwal, 2014, pp. 1-2). Qualitative methods and descriptive analysis allow analysis through exploration, discovery, to inductive logic to explain the object of the research through phenomenon (Nugrahani, 2014, pp. 31-32). Data collection in this research is done by literature studies as the basis for the information needed by researches regarding the phenomenon in Myanmar. Through literature studies, the data obtained in the form of books, journals, research reports, newspapers, scientific articles, documents, and interview results are utilized to form an understanding of the crisis in Myanmar and international efforts to respond humanitary violations in Myanmar.

\section{LITERATURE REVIEW: INTERNATIONAL COOPERATION}

International cooperation often occurs and is very closely related in the life of the international community and the life of the state with the various actors who run it. As stated by Joseph Greico in his work, international cooperation will occur if there are objective interests. Cooperation can take place in a variety of different contexts, most relationships and interactions in the form of cooperation occur directly between two or more actors who have the same interests or problems at the same time. Other forms of cooperation carried out by countries that are in international organizations or institutions (Greico, 1990). Then there is according to K.J Holsti explaining international cooperation is cooperation carried out by countries that are interconnected by proposing solutions, negotiations or talks about the problems at hand. Express various technical evidences to support the problem and end the negotiations by forming an agreement or mutual understanding that is agreed upon by all parties (Holsti, 1992).

In short, international cooperation was formed with the aim of increasing mutual prosperity. International cooperation has various forms according to the interests and objectives of the parties involved. According to Pfaltzgraff in his work, international cooperation is divided into 3 parts, namely (Pfaltzgraff, Dougzgherty, \& Robert, 1997):

1) Bilateral Cooperation

Cooperation or agreement conducted made by two countries that are Treaty Contracts

2) Regional Cooperation

Cooperation or agreement made by several countries located in an area and is limited to Law Making Treaty and Treaty Contract

3) Multilateral Cooperation

Cooperation or agreements made by various countries that are not limited to certain areas and have an international nature with Law Making Treaty.

\section{ROHINGYA CONFLICT BACKGROUND}

The Rohingya are a highly persecuted Muslim group who faced discrimination from their nation, and are not considered citizens by the Government of Myanmar. They are one of the many ethnic minorities in the country and represent the largest percentage of Muslims in Myanmar (BBC News, 2020). In particular, the suffering and displacement of the Rohingya people first began in 1978, when General Ne Win launched "Operation Dragon" to exterminate illegal foreigners. Its main purpose was to frighten the Muslims and force them to leave Arakan. The conflict took new forms of violence in 2012. Buddhist nationalist groups have boycotted Muslim shops, expelled Muslims from Myanmar, and attacked Muslim communities. After waves of violence and riots in June and October 2012, more than 100,000 Rohingya Muslims were displaced and hundreds more were killed (Global Conflict Tracker, 2021).

The Myanmar government's discriminatory policies have been going on since the late 1970s and have forced hundreds of thousands of Rohingya Muslims to flee their homes in the Buddhist country. Most have crossed to Bangladesh, while others have already gone to sea to reach Indonesia, Malaysia and Thailand. In early 2017, there was another return of violence including rape, murder and arson that fueled the Rohingya exodus. The Myanmar Security Forces claim that they have recently launched a campaign to restore stability in the western region of the country. The Myanmar government has institutionalized discrimination against the Rohingya through restrictions on marriage, family planning, employment, education, religious choice and freedom of movement. Widespread poverty, poor infrastructure and a lack of job opportunities have exacerbated divisions between Buddhists and Rohingya Muslims. This tension is influenced by religious differences which sometimes escalate into conflict (Albert \& Maizland, 2020). 


\section{Rohingya to Myanmar Military Coup: The Role of International Organizations in Humanitarian Violations and}

Myanmar's Democracy Deprivation

Ethnic Cleansing is an attempt to drive Rohingya out of the country or at least to refugee camps. The Rohingya are not considered citizens of Myanmar. They have many boundaries and their land has been confiscated by the government and military forces. They are not accepted by the local Buddhist community. Rakhine Buddhists believe that the increasing number of Muslims in this area poses a risk to their identity, who perceive Muslim culture as a threat to Buddhist culture (Mazhar \& Goraya, 2016).

\section{MYANMAR MILITARY COUP BACKGROUND}

On February 1, 2021, the Myanmar military took control after the general election won by the NLD Party, Ang San Suu Kyi. The opposition, namely the Myanmar military, demanded a re-election because they claimed that the election was rigged. However, this claim is not supported by concrete evidence, so it cannot be justified (Cuddy, 2021). Ang San Suu Kyi, the country's de facto leader, President Win Myint, and other senior members of the National League for Democracy (NLD) party were detained in the capital, Naypyidaw, on Monday. A range of charges have been faced, including official state covert action, possessing illegal walkie-talkies, and publishing information that could provoke fear.

Now, military chief Min Aung Hlaing has taken over state power. This is a moment long used to successfully maintain the power of the Tatmadaw, even as the country moves towards democracy. Residents of the country's largest city, Yangon, say history is repeating itself, with fears that the following years will be meaningless. The military justified their takeover by alleging widespread voter fraud during the November 2020 general election that gave Suu Kyi's party another overwhelming victory and dashed hopes for some military figures that the opposition party they supported could take power democratically (Regan, 2021). But according to analysts, the coup was driven by the power and personal ambition of a military chief who felt he had lost control and respect.

Assistance Association for Political Prisoners (AAPP) documented that at least 133 government officials and legislators and 14 activists have been detained since Monday. Suu Kyi is under house arrest, charged with violating the Export-Import Act, while ousted President Win Myint is accused of violating the Natural Disaster Management law. On Sunday, thousands of people took to the streets in Yangon for the second day in a row to stage a massive protest against the military's seizure of power. Myanmar will be under the military's will - and a state of emergency - for at least a year and Min Aung Hlaing said elections would be held once the fraud investigation is complete, although analysts say they want to ensure Suu Kyi does not run (Regan, 2021).

\section{INTERNATIONAL EFFORTS IN RESPOND TO THE CONFLICTS OCCURING IN MYANMAR}

The world has focused its attention on the ongoing conflict in Myanmar. Despite the ongoing COVID-19 pandemic, international organizations see the conflict in Myanmar as a serious problem if left untreated. Various countries have criticized Myanmar, and urged the parties involved to refrain from further action and engage in dialogue to resolve the conflict as soon as possible. The role of international organizations in the Myanmar issue can be seen from several efforts, including ASEAN as a regional international organization who is responsible to conduct peace and stability in the region. Indonesia, as a country that is in the same region as Myanmar, is also concerned about this because if it is not handled it can become a seed for the emergence of problems in the area and safety of the Myanmar people. For starters, citing the Minister of Foreign Affairs of Indonesia, Retno Marsudi, Indonesia has urged the parties involved to exercise restraint and pursue dialogue in finding solutions to the challenges they are experiencing. Indonesia also urges to pay attention to the principles of the ASEAN Charter, including compliance with the rule of law, good governance, democratic principles, and constitutional governance (Assegaf, 2021).

In terms of diplomacy, Indonesia can also play an important role. Indonesia may not be able to intervene directly due to the fact that it is not involved in the Myanmar national conflict. But despite its inability to intervene directly in the conflict, Indonesia can use diplomacy to negotiate with other ASEAN members to resolve the conflict. As we all know, Myanmar is a member of ASEAN, and so is Indonesia. ASEAN will be a diplomatic platform for conflict resolution. Indonesia as the older brother of ASEAN can be a driving force for negotiations so that ASEAN members can reach a consensus on conflict resolution. ASEAN may uphold the "Principle of Non-Interference" but it is certain that there is a consensus among ASEAN members to finally intervene and take action in the Myanmar conflict as a way to maintain stability in the region and to prevent further crimes against humanity in the country.

Regarding the Rohingya issue, the Indonesian government must further strengthen its diplomatic approach to resolving the conflict that has been carried out. Humanitarian assistance is an important need at this time, but ensuring that Myanmar solves the Rohingya problem and does not use a repressive approach is also something that must be done. The Indonesian government plays an important diplomatic role that has been accepted by the Myanmar government, along with the bilateral cooperation with the Myanmar military. In this regard, maximizing the role of Indonesia's diplomacy with the Myanmar government is one of the possible actions that can be taken immediately to stop the violence that is not prolonged and reach an agreement to prevent future threats (HRWG, 2017). Indonesia's efforts to address the Rohingya crisis are based on high-level diplomacy and humanitarian assistance. Indonesia provided humanitarian assistance to the camps with the Indonesia Humanitarian Alliance (IHA) coalition led 


\section{Rohingya to Myanmar Military Coup: The Role of International Organizations in Humanitarian Violations and Myanmar's Democracy Deprivation}

by Nahdatul Ulama and Muhammadiyah. But President Jokowi is in no condition to take dramatic action because it will jeopardize his relationship with Myanmar (Institute for Policy Analysis of Conflict, 2018).

On the other hand, in response to the ongoing coup in Myanmar, Indonesia is rallying support for a selective and constructive response to the coup and for holding a special summit among ASEAN members. Some countries may refuse to cooperate, but Indonesia with the power of diplomacy can convince the country to focus on transitioning back to democracy as it has done since the military took power. Realistically, Indonesia is not in a position to help facilitate this process, but it also has other options. Constructive dialogue would be a possible solution for ASEAN. ASEAN is in a strong position to impose sanctions on the military, given the close economic ties between Myanmar and the rest of Southeast Asia. ASEAN is currently putting these possibilities into action (Haan, 2021).

Other countries outside ASEAN have also taken action to respond to the conflict in Myanmar. Several countries, for example, New Zealand announced the suspension of all high-level political and military contacts with Myanmar, imposed travel bans on Myanmar's military leaders, and suspended aid to the government. On the same day, the European Union imposed a series of restrictive measures against Myanmar, including an embargo on arms and equipment that may be used for internal repression, as well as restrictive measures against 14 senior military officers. Canada also imposed additional sanctions on the nine military leaders involved in the coup. These sanctions can have far-reaching international consequences. It is imperative that countries that impose sanctions on Myanmar take effective steps to enforce action. It is also important for governments to act together, target sanctions appropriately, and focus on effective communication to military leadership about what they need to do to get those measures lifted. This condition can cause Myanmar to finally resolve the conflict for sanctions to be lifted by the countries that enforce it (Human Rights Watch, 2021).

The widespread blood fighting waged by Myanmar's military has also been condemned by the United Nations. Alice Nderitu, Special Advisor for the Prevention of Genocide, and Michelle Bachelet, High Commissioner for Human Rights, strongly condemn the Myanmar military's widespread, deadly and increasingly systematic attacks on protesters and other crimes and violations of humanity since the military took power on February 1 . Senior officials also asked the Security Council to build on its March 10 statement condemning the violence, among other things, and for the Association of Southeast Asian Nations (ASEAN) and the wider international community to act immediately to protect people from atrocities. Although the State has the primary responsibility to protect its population, in cases where it does fail, the international community "must take timely and collective action in accordance with the Charter of the United Nations to protect the civilian population at risk of atrocities (Hein, 2021)

\section{VII.CONCLUSION}

The escalation of the humanitarian conflict and the deprivation of democracy by the Myanmar people, requires joint handling in order to avoid further expansion of the conflict. In this case, neighboring countries such as Indonesia have an important role as a driver of mediation in regional forums to resolve conflicts in Myanmar. Not only that, criticisms from other countries are the first step in responding to the conflict. However, simply condemning is not enough to tackle crimes against humanity in Myanmar. For this reason, ASEAN, as a diplomatic platform in the Southeast Asian region, must be put forward and reach a consensus for finally intervening in the Myanmar conflict, which is taking more and more lives. The United Nations with the principle of responsibility to protect can also play a role in overcoming the conflict, considering that the conflict has resulted in crimes against humanity that cannot be tolerated.

\section{REFERENCES}

1) Albert, E., \& Maizland, L. (2020, January 23). The Rohingya Crisis. Retrieved from Council on Foreign Relations: https://www.cfr.org/backgrounder/rohingya-crisis

2) Assegaf, F. (2021, February 1). Indonesia Presses for Inter-Party Dialogue to Resolve Myanmar Conflict. Retrieved from ANTARA News: https://en.antaranews.com/news/167124/indonesia-presses-for-inter-party-dialogue-to-resolvemyanmar-conflict

3) BBC News. (2020, January 23). Myanmar Rohingya: What You Need to Know about the Crisis. Retrieved from BBC News: https://www.bbc.com/news/world-asia-41566561

4) Cuddy, A. (2021, April 1). Myanmar Coup: What is Happening and Why? Retrieved from BBC News: https://www.bbc.com/news/world-asia-55902070

5) Global Conflict Tracker. (2021, April 7). Rohingya Crisis in Myanmar. Retrieved from Council of Foreign Relations: https://www.cfr.org/global-conflict-tracker/conflict/rohingya-crisis-myanmar

6) Greico, J. (1990). Cooperation Among Nation, Europe, America, \& Nontariff Barriers to Trade. New York: Cornell University Press. 
Rohingya to Myanmar Military Coup: The Role of International Organizations in Humanitarian Violations and Myanmar's Democracy Deprivation

7) Haan, J. d. (2021, February 24). Can Indonesia Rally an ASEAN Response to the Myanmar Coup? Retrieved from Future Directions International: https://www.futuredirections.org.au/publication/can-indonesia-rally-an-asean-response-to-themyanmar-coup/

8) Hein, Z. (2021, Maret 28). Myanmar: Top UN Officials Condemn Military's "Shameful, Cowardly" Attacks on Peacefull Protesters. Retrieved from United Nations News: https://news.un.org/en/story/2021/03/1088482

9) Holsti, K. (1992). Politik Internasional: Suatu Kerangka Teoritis. Bandung: Binacipta.

10) HRWG. (2017, September 4). Diplomacy of the Indonesia-Myanmar Permanent Conflict Resolution Needed to Prevent the Continuity of Brutality and Violence. Retrieved from HRWG: https://hrwg.org/2017/09/04/diplomacy-of-theindonesia-myanmar-permanent-conflict-resolution-needed-to-prevent-the-continuity-of-brutality-and-violence/

11) Human Rights Watch. (2021, February 18). Myanmar, Sanctions, and Human Rights. Retrieved from Human RIghts Watch: https://www.hrw.org/news/2021/02/18/myanmar-sanctions-and-human-rights\#_What_sanctions_have_1

12) Institute for Policy Analysis of Conflict. (2018). Indonesia and The Rohingya Crisis. Jakarta: IPAC: Institute for Policy Analysis of Conflict.

13) Maizland, L. (2021, February 10). Myanmar's Troubled History: Coups, Military Rule, and Ethnic Conflict. Retrieved from Council on Foreign Relatinos: https://www.cfr.org/backgrounder/myanmar-history-coup-military-rule-ethnicconflict-rohingya

14) Mazhar, M. S., \& Goraya, N. S. (2016). Plight of Rohingya Muslims. Journal of the Research Society of Pakistan Vol. 53 No. 1, 27-40.

15) Nugrahani, F. (2014). Metode Penelitian Kualitatif. Surakarta: Cakra Books.

16) Pfaltzgraff, J., Dougzgherty, \& Robert, L. (1997). Contending Theories. New York: Row Publisher.

17) Regan, H. (2021, Februari 8). Myanmar's Military Overturned Democratic Election. Now They're Warning Protesters not to Destroy Democracy. Retrieved from ABC 57: https://www.abc57.com/news/myanmars-military-overturned-ademocratic-election-now-theyre-warning-protesters-not-to-destroy-democracy

18) Regan, H. (2021, February 8). Why the Generals Really Took Back Power in Myanmar. Retrieved from CNN World: https://edition.cnn.com/2021/02/06/asia/myanmar-coup-what-led-to-it-intl-hnk/index.html

19) White, H., \& Sabarwal, S. (2014). Quasi-Experimental Design and Methods. Florence: United Nation's Children Fund. 